\title{
THE LEGAL THEORY OF ATTORNEY FEE SHIFTING: A CRITICAL OVERVIEW
}

\author{
Thomas D. Rowe, JR.*
}

With its general rule that each side in civil litigation has ultimate responsibility for its own lawyer's fees and that the system will not require the loser to pay anything toward the winner's representation, this country stands in a sinall minority among the industrialized deinocracies. ${ }^{1}$ The English routinely include an assessment for a reasonable attorney's fee in the costs to be borne by a losing party; 2 the usual rule on the Continent is similarly to assess the loser for at least part of the winner's attorney fees. ${ }^{3}$ In recent decades, the American rule of no attorney fee shifting has conne under increasing questioning and criticism. ${ }^{4}$ At the same time, the rule has been riddled with ever more numerous exceptions at both state and federal levels. ${ }^{5}$

Discussion of fee shifting rules in cases, legislative histories, and commentary has tended to remain ad hoc, understandably focusing on interests and concerns surrounding a particular possible or existing exception to the American rule. There exist, indeed, several different sorts of reasons why a legal system might choose a policy of requiring losing hitigants to pay winners' legal fees in some or all cases. This

* Associate Dean for Research and Professor of Law, Duke University School of Law. B.A. Yale, 1964; M.Phil. Oxford, 1967; J.D. Harvard, 1970. The bulk of the work for this study was done while the author was a Fellow in Administration of Justice, Office for Improvements in the Administration of Justice, United States Department of Justice, 1980-1981. For their support and criticisin I am grateful to Professor Maurice Rosenberg, Professor Horace B. Robertson, Peter F. Rient, and William R. Yeomans. The views expressed here are my own and do not necessarily represent the position of the Department of Justice.

1. See generally, eg., W. Pfennigstorf, Legal Expense Insurance: The European EXPERIENCE IN FINANCING Legal. SeRvices 39 (1975) (table of practice in eight Continental nations); Note, The Private Attomey General and the Public Advocate: Facilitating Public Interest Litigation, 34 RuTGers L. Rev. 350, 351 n.7 (1982). The main exception to the general pattern outside the United States is Japan, which follows the American rule with the significant exception of fee shifting in favor of prevailing tort plaintiffs. See Kojima \& Taniguchi, Access to Justice in. Japan-Japanese National Report on Access to Justice, in 1 ACCESs to Justice 689, 705 (1978). See also W. PFennigstorf, supra, at 39 (fee awards in Belgium limited to amounts fixed by law regardless of actual fees).

2. See, e.g., R. Jackson, The Machinery of Justice in Englañd 518 (7th ed. 1977).

3. See W. Pfennigstorf, supra note 1, at 39.

4. See, e.g., Comment, Financial Barriers to Litigation: Attorney Fees and the Problem of Legal Access, 46 ALB. L. REv. 148, 148-49 (1981).

5. See, e.g., Alyeska Pipeline Serv. Co. v. Wilderness Soc'y, 421 U.S. 240, 260-61 n.33 (1975) (listing federal fee shifting statutes). 
article attempts to bring together the several mam rationales and to provide a critical evaluation of them-an intellectual effort that may have value to judges, practitioners, legislators, and academics as they confront issues of the extension and application of fee shifting scheines. ${ }^{6}$ It also explores the implications of basing a fee shifting rule on one or another of the rationales for a range of specific issues $m$ the formulation and application of the, rule, finding the rationales more farreaching than generally assumed. Before beginning to examine the rationales, the article's first section briefly suggests some classifications to keep the several different strains im some context.

\section{General Types of Fee Shifting Rationales}

At first glance fee shifting systems appear to rest on two basic concerns-equity and incentives. Considerable equitable appeal attaches, for example, to the idea of making a successful party whole. Other rationales, such as discouraging nuisance litigation, focus primarily on the supposed incentive effects of fee shifting practices. Fee shiftimg rationales do not, however, lend themselves to ready division into two categories on the basis of these two sorts of concerns; the same rationale can draw on both. For example, the use of shifting pumitively against vexatious litigants may not only discourage harassing tactics; it can also satisfy our sense of justice to see the user of such tactics get a well-deserved punishinent.

Despite this frequent overlap, it seens possible and useful to identify major strains underlying the several fee shifting rationales more precisely than speaking only of "equity" and "imcentives." The "incentives" branch lends itself to subdivision on the basis of effects on individual litigants in particular cases versus external effects, such as the impact of litigation results and incentives on those who are not parties to a case. Thus the different concerns underlying fee shifting rationales have three major strains-equity, litigant mcentives, and externalities.

Under the heading of equity, the concerns can be broken down into equity for parties suffering legal mjury, such as the provision of make-whole relief; equity in the punishinent of defendants for aggravated primary conduct and of parties for misconduct in litigation; and equity to winners, such as the rationale often given for the English imdemnity rule of two-way shifting. Litigant incentives in gross consist simply of encouraging desirable and discouraging undesirable behavior

6. The rationale or rationales behind a fee shifting scheme will not, of course, always by themselves determine the features of the scheme. Encouraging test litigation, for example, could support the payment of fees out of public funds rather than by the losing party, but governmental budget constraimts might rule out such an approach. 
in the bringing and conduct of litigation. In fine they range over the decisions whether to sue and whether to resist, choices whether to use various tactics, and decisions about amount and timing of settlement. External effects are such matters as the utility of precedent generated, the effects of injunctions banning conduct affecting many, and general deterrence of primary conduct both from a possibly increased threat of litigation and froin the prospect of having to pay an increased portion of the costs of litigation.

\section{Specific Rationales Used to Justify Fee Shifting}

This article identifies six rationales that commonly appear as justifications for fee-shifting. The first is a sense of simple fairness: the idea that it is only just for the loser to have to pay, at least in considerable part, the winner's legal costs appears to be a major underpinning of the English indemnity rule. The second, the theme of inaking a litigant financially whole for a legal wrong suffered, is probably inost familiar as the idea of coinpensation in the substantive law of remedies. A punitive emphasis on fee shifting to deter and punish misconduct, either in litigation or in the underlying transaction, is a third rationale. Fourth, the "private attorney general" theory justifies a fee award on the basis of the public usefulness of advancing a particular type of claim. A fifth justification is a desire to affect the relative strengths of the parties, a theine that appears in discussion of schemes for fee shifting against government, particularly when the private party involved is an individual or a sniall concern. Finally, a fee shifting schenie can be supported by its expected or actual economic incentive effects, such as its impact on the rate of pursuit of claims, on parties' settlement incentives, and on the speed of disposition of cases. ${ }^{7}$

\section{A. Fairness and the Indemnity Rule.}

In the literature of the other developed nations of English legal heritage, it is surprising how rarely one finds any effort at theoretical justification for the indemnity or "two-way"s fee shifting rule." To the

7. Some of the purposes discussed here are "ultimate" in the sense that they do not depend for their justification on pursuit of some further goal. Others, such as encouraging a particular type of action, do rest on such a connection and can be described as "instrumental." When the further goal is a broader substantive one, such as encouraging private civil rights enforcement, this study does not go beyond consideration of the instrumental purpose.

8. This article uses the term "two-way" fee shifting as shorthand for the system in which the loser pays the winner's attorney fee, be the winner plaintiff or defendant. There also exist "oneway" shifting schemes, most often with prevailing plaintiffs but not successful defendants entitled to recover counsel fees. The general American practice-absent a statute, contractual provision, or exceptional circumstances-provides no fee shifting; each party is responsible for paying its 
extent that any main theme comes through at all, it is that awarding fees is not to punish a losing party but rather to provide indemnity for the winner. ${ }^{10}$ Such explanations as exist often go only that deep, not elaborating on why the loser should not feel punished or on what purpose "indemnity" serves" beyond speaking tautologically of reimbursing the winner for at least a portion of his legal fees. ${ }^{12}$ Such assertions seein to presume that the idea of indemnity should suffice by itselfthat justice simply requires that losers pay winners' counsel fees. The near-universality of the practice may have insulated it from the kind of questioning that could produce deeper explanations; in any event, the American example shows that it is not self-evident to everyone that the loser should have to pay. ${ }^{13}$

The argument for general indemnity initially having greatest intuitive appeal is that the prevailing party, having been adjudged to be in the right, should not suffer financially for having to prove the justice of his position. ${ }^{14}$ Justice for the winner, however, is not the only relevant

own lawyer, whatever the outcome. See, eg., Alyeska Pipeline Serv. Co. v. Wilderness Soc'y, 421 U.S. 240, 247-50 (1975).

9. See, eg., R. JACKson, supra note 2, at 518 (stating English rule without giving reasons); cf. Bokelinann, "Rechtswegsperre" durch Prozesskosten, in 7 ZEITSCHRIFT FÜR RECHTSPOLITIK 164,169 (1973) (stating that origin of German loser-pays rule is little discussed and that the rule is commonly justified as embedded in popular consciousness).

10. See, e.g., M. ORKIN, THE LAW OF COSTS 14 (1968) (Canada); $c$. Clarke v. Hart, 10 Eng. Rep. 1443, 1457 (H.L. 1858) (opinion of Cranworth, L.) ("costs ought never to be considered as a penalty or punishment, but inerely a necessary consequence of a party having created a hitigation in which he has failed"). But cf. Jacob, Aecess 10 Justice in England, in 1 ACCESs to Justice 417, 440 (1978) (concept underlying English indemmity practice is that loser was at "fault" in contesting proceeding). On this "fault" notion, see infra text accompanying note 19. Other justiciations mentioned include providing full compensation for an injured party and detcrring abuse of judicial processs. See Comment, supra note 4, at 151. For discussion of the compensation rationale, see infra text accompanying notes 26-37. For discussion concerning fee awards to deter misuse of legal process, see infra text accompanying notes $42-43$.

11. See, e.g., M. ORKIN, supra note 10, at 14.

12. See, eg., Preferred Gen. Agency v. Raffetto, 391 P.2d 951, 954 (Alaska 1964) (purpose of providing prevailing party with partial compensation for his costs).

13. Underlying the divergent approaches may be different casts of mind, producing contrary presumptions as starting points for thinking about who should bear hitigation costs. The English seem to begin from an attitude that losers shonld naturally pay, while Americans tend to want affirmative justifications to support fee shifts. Compare, e.g., Clarke v. Hart, 10 Eng. Rep. 1443, 1457 (H.L. 1858) (opinion of Cranworth, L.) (costs "merely a necessary consequence of a party having created a litigation in which he has failed") with, e.g., Letter from Benjamin N. Cardozo to H.H. Nordlinger, quoted in G. Hellman, Benjamin N. Cardozo: AMERICAN Judge 150 (1940) ("Some of the losses that are incidental to the establishment of rights and the redress of wrongs through the processes of courts should be allowed, as a matter of social engineering, to he where they fall. Very likely, heavier burdens should be inposed where there is evidence of bad faith or mere dogged perversity.").

14. See, eg., D. Dobbs, Handiook of the Law of Remedies: Damages-Equity-ResTITUTION \& 3.8, at 201 (1973); $c$. ARIZ. Rev. StaT. ANN. \& 12-341.01(A)-(B) (1982) (permitting award of reasonable attorney's fees to prevailing party in contested contract actions and stating 
consideration. One can agree with the ideal of restoring the prevailing party to the position he would have enjoyed had litigation not been necessary while still recognizing possible conflicting equities: there can remain problems with taking the noney for the restoration froin the loser. A defeated party, in particular, inay frequently appear to have been justified and reasonable in pressing a strong but ultimately unsuccessful claim or defense. Such a situation involves a winner who deserves reimbursement-and a loser with plausible argument that he should not have to do the reimbursing. In theory the system might step in and solve the problem with a payment out of general revenues. ${ }^{15}$ In practice that seems unlikely, forcing a choice between the conflicting equities.

Plausible reasons do exist for making that choice in favor of general indemnity instead of no shifting or internediate approaclies, but they will strike inany as inconclusive at best. A first possible argument is that the winner's is the stronger of the two equities because he prevailed. But the winner's incontestable entitlement from victory on the merits is no more than a judgment on the inerits. Once the winner has gotten this judgment, a further, separable issue concerning fees remains; and a superior claim or defense on the merits does not automatically translate into superior equity on fees. The loser in a test case making unexpected new law, for example, has an especially appealing argument not to have to pay. Deriving a winner's fee equity from victory on the merits inerely presumes an answer to the question whether that victory should entitle the winner to more than judgment on the merits. Resolving the problem of conflicting equities requires a look at further considerations.

One consideration would be the effect of a system's substantive law, procedural practices, and judicial staffing. If these factors make litigation outcoines generally rather predictable, then indemnity makes some sense on the ground that the loser probably should have known better and should not have imposed on others the costs of an unnecessary proceeding. Considerable support for such an attitude exists in the unitary English system, with its nonpolitical bencli and near-total abolition of civil jury trials. Practices in this country, by contrast, leave more room for the feeling that losers will often not have been unrea-

that awards "should be made to mitigate the burden of the expense of litigation to establish a just claim or a just defense").

15. See Gold, Controlling Procedural Abuses: The Role of Costs and Inherent Judicial Authority, 9 OTTAWA L. REv. 44, 61 (1977) (supporting state payment of both sides' fees when both acted reasonably). 
sonable or unjustified in insisting on litigation. ${ }^{16}$ A second consideration is that if indemnity is regarded as likely to discourage litigation (which it often is, ${ }^{17}$ although there is inadequate empirical evidence on the question) and if litigation is soinewhat frowned upon, then indemnity seems desirable. American attitudes, however, tend to regard litigation as everyone's right and to emphasize the importance of not excessively hindering access to justice. ${ }^{18}$

Other conceivable justifications, as later sections will develop more fully, support fee shifting only in some situations and do not provide a basis for general indemnity. To suggest that losers should pay because they were at fault in contesting proceedings ${ }^{19}$ is to assume-untenably-that one will always be able to say that a loser with a reasonable case should have done other than pursue it to judgment. General indemnity is in effect a species of strict liability; it does not advance discussion to attenipt to justify it on a fault basis.

General indemnity, finally, raises enough problems to give even its supporters pause. In cases so close and difficult or important that both sides have ample justification to litigate, it can seem unfair and harsh to saddle one with the fees of both. ${ }^{20}$ There is also reason to question whether the incentive effects of general indemnity are all good, and it nay be possible to construct systems that stop short of general indemnity and avoid some of its bad effects. ${ }^{21}$ To inention just a few examples of sucl effects, indemnity nray excessively deter the pursuit of meritorious but not clear-cut claims by middle-class litigants, ${ }^{22}$ lead to reciprocal escalation of expenditure on legal services, ${ }^{23}$ and pose a ma-

16. See R. Posner, EConomic ANalysis of LAw \& 21.8, at 452-53 (2d ed. 1977); cf. Letter from Benjamin N. Cardozo to H.H. Nordlinger, supra note 13 ("I have seen enough of the judicial process to know its imperfections. I would not lay too heavy a burden upon the unsuccessful hitigant."). Moreover, uncertainty about likely outcomes will impair some of the incentive effects that fee shifting is supposed to have. For instance, no system can deter weak claims and defenses and encourage strong ones unless it is possible for parties to predict relative strengths and weaknesses. See generally Mause, Winner Takes All: A Re-Examination of the Indemnity System, 55 IOWA L. REv. 26; 47 (1969).

17. See, e.g., Williams, Fee Shifting and Public Interest Litigation, 64 A.B.A. J. 859,860 (1978).

18. See generally, eg., Corboy, Contingency Fees: The Individual's Key to the Courthouse Door, 2:4 Litigation 27 (Summer 1976).

19. See Jacob, supra note 10 , at 440.

20. See infra text accompanying note 95.

21. See generally Mause, supra note 16.

22. See, e.g., Griswold, Two Branches of the Same Stream, 14:4 Harv. L. Sch. Bull. 4, S (Feb. 1963); Memorandum by the Council, Indemnity Rule in Litigation, in LaW Soc'y, ANNual REPORT OF THE COUNCIL AND ACCOUNTS 73, 73 (1963-1964); Comment, Distribution of Legal Expense Among Litigants, 49 Y ALE L.J. 699, 702-03 (1940).

23. See e.g., Committee on Supreme Court Practice and Procedure, Final Report 153, 233-34, 236 (1953) [hereinafter cited as FINAL REPORT]; Goodhart, Current Judicial Reform in 
jor threat to the public interest bar. ${ }^{24}$ At the very least, a system following general indemnity should remain open to arguments for significant exceptions to its rule. ${ }^{25}$

\section{B. Compensation for Legal Injury.}

Another argument for fee shiftimg that has a strong intuitive appeal is that refusing to award fees demes a wronged party full compensation for his injury. A classic statement of this argument appears in a 1925 report of the Judicial Council of Massachusetts, in which the Council supported the adoption of "a systein of substantial costs," asking: "On what principle of justice can a plaintiff wrongfully run down on a public highway recover his doctor's bill but not his lawyer's bill?"26 Undeniably, the American rule's effect of reducing a successful plaintiff's recovery by the amount of his lawyer's fee conflicts with the inake-whiole idea underlying nuch of the law of remedies.

Moreover, the impulse to award make-wliole compensation can properly rest on more than just out-of-court conduct inflicting injury. A party subjected to a baseless suit, forced to run up legal fees to overcome a groundless defense, or subjected to unjustified tactics in litigation, has an appealing claim for recompense of the legal fees he should not have had to spend, whether or not his claim is treated as a separate cause of action. Thus, lowever widespread its rejection in American practice, ${ }^{27}$ the prima facie argument for fee shifting based on making a

England, 27 N.Y.U. L. REv. 395, 405-06 (1952); Mause, supra note 16, at 36; Memorandum by the Council, supra note 22 , at 75.

24. See, eg., Williams, supra note 17, at 862; The Awarding of Attorneys' Fees in Federal Courts: Hearings Before the Subcomm on Courts, Civil Liberties, and the Administration of Justice of the House Comm. on the Judiciary, 95th Cong., 1st \& 2d Sess. 59 (1977-1978) (statement of Susan Gross) [hereinafter cited as House Hearings].

25. The argument in the text does not imply that practice in America is better thought out than in indemnity rule jurisdictions. The American system may have even less coherence than those following general shifting, because it normally leaves fees where they fall while shifting other costs of litigation. The explanations for the fee-cost divergence in this country seem mainly historical. See generally Comment, Court Awarded Attorney's Fees and Equal Access to the Courts, 122 U. PA. L. Rev. 636, 640-44 (1974); see also Baez v. United States Dept. of Justice, 684 F.2d 999, 1002-03 (D.C. Cir. 1982) (per curiam) (fee-cost distinction justified by difference in amounts involved and greater ease of calculating costs). Even as to the costs shifted in this country, "[t]here seems [sic] to be no underlying principles of law involved other than the prevailing party should be reimbursed for a portion of the expense of the hitigation." Payne, Costs in Common Law Actions in the Federal Courts, 21 VA. L. REV. 397, 400 (1935) (footnote omitted).

26. Judicial Council of Massachusetts, First Report, 11 MAss. L.Q. 7, 64 (1925); see also, e.g., D. DoBBs, supra note $14, \S 3.8$, at 201 .

27. For a recent example of the conventional rejection of the make-whole rationale as a basis for fee shifting, see Summit Valley Indus. v. Local 112, United Bhd. of Carpenters, $102 \mathrm{~S}$. Ct. 2112, 2116-17 (1982). The reasons given by the Court do not question the basic soundness of the make-whole argument but raise collateral problems. Moreover, the reasons are largely so tenuous 
successful party financially whole for legal injury seems persuasive.28

At this point the reader may have begun to wonder if the distinction between the justifications for indemnifying winners generally, evaluated critically in the preceding section, and the inake-whole rationale, receiving kinder treatment here, is entirely too fine. To the contrary, it is quite basic and parallels the distinction between strict and fault liability in tort law. General indemnity requires a loser to pay a winner's fees regardless of whether the loser did anything wrong. The inake-whole rationale as defined here, by contrast, requires fee shifting only if the loser was somehow at fanlt-either in his primary conduct or in the course of litigation-in forcing the winner to spend money on legal services. The presence in the loser's conduct of fault that causes legal expense eliminates the problen of conflicting equities that creates difficulty for atteinpts to justify general indemnity.

However persuasive the make-whole rationale may be as a basis for awarding attorney fees, it does not go so far as to support a systein of general indemnity. The rationale has incontestable application only when a plaintiff or counterclaiming defendant prevails on a claim for which make-whole relief is an appropriate remedy for the other side's substantive wrong, or when an unjustified step in litigation forces needless expenditure on legal fees. The former description includes negligence damage claims and much of the rest of tort law, ${ }^{29}$ plus such matters as contract claims for expectation dainages and eminent domam proceedings. Discovery abuse is a prominent example of the latter. Yet the make-whole rationale, to cite perhaps the most obvious instance, does not justify fee awards to plamtiffs prevailing on claims for restitution because the idea of restitutionary relief is not to make the plaintiff whole but rather to prevent unjust enrichment of the defendant. ${ }^{30}$ Another illustration of a type of case in which the make-

as to make it appear that the rejection rests more on settled practice than on anything else. See id. at 2117 ("deterrent effect that fee shifting would have on poor litigants with meritorious claims," which is inaccurate of a primarily one-way rule based on compensation for substantive legal wrong; threat to "principle of indcpendent advocacy" froin judges having to rule on both merits and fees, which could be circumvented by use of taxing masters as in England).

28. Accord, Mause, supra note 16, at 30 . The claim to be made whole has strong foundation in economic theory as well as in equity. To the extent that inake-whole compensation imposes the costs of wrongful conduct on negligent injurers or other legal wrongdoers, it provides the economically efficient amount of deterrence for such conduct. See R. POSNER, supra note 16, \& 6.12, at 143. But cf. Diamond, Single Activity Accidents, 3 J. LeGAL STud. 107, 163 (1974) (noneconomic influences on decisions about degree of care).

29. Cf. Kojima \& Taniguchi, supra note 1, at 705 (award of attorney fees to prevailing tort plaintiffs in Japan, which otherwise follows the American rule).

30. See D. DoBBS, supra note $14, \S 4.1$, at 223-27. If a defendant has to pay the plaintiff the entire anount by which the defendant was unjustly enriched, the purpose of restitution is fully served without the defendant's having further to compensate the plaintiff for his legal fees. There 
whole rationale would not support a fee award to a prevailing plaintiff is an action for a declaratory judgment growing out of good faith disagreement over the meaning of a provision of law or contract.

Most importantly, the make-whole rationale does not im many or most cases seem to support shifting in favor of a defendant prevailing on the merits. The positions of plaintiff and defendant may seem parallel; prevailing defendants initially can appear as entitled to full restoration as prevailing plaintiffs are to full compensation. ${ }^{31}$ But the persuasive reason for making a successful plaintiff whole is that he suffered a legal wrong appropriately remediable by compensation. Our system does not regard bringing (or, for that matter, defending) a losing case-without more-as the infliction of a legal wrong. ${ }^{32}$ It does regard malicious prosecution as an actionable wrong, ${ }^{33}$ for which.counsel fees from the successful defense are recoverable as an element of daunages. ${ }^{34}$ Some jurisdictions go further and provide for fee shifting when the bringing of an action seems by some measure, other than sheer lack of success, to have been unjustifiable. ${ }^{35}$ It is between such defendants, subjected to malicious prosecution or a baseless action, and plaintiffs entitled to be made whole that there does seem to be a parallel entitlement to an award of fees. ${ }^{36}$ Similarly, plaintiffs entitled to relief such as restitution, and prevailing defendants not subjected to inalicious prosecution or to an otherwise unjustifiable claim, are in parallel positions in that the make-whole rationale does not support awarding them fees. Perhaps plaintiffs and defendants of these latter varieties should benefit from fee shifting, but if so on grounds other than a claim to be made whole for a legal imjury. ${ }^{37}$

may, however, be other reasons supporting fee shifting in sorne restitution cases. See infra text accompanying note 81 .

31. See, e.g., Judicial Council, supra note 26, at 64 ("And on what principle of justice is a defendant who has been wrongfully haled into court unade to pay out of his own pocket the expense of showing that he was wrongfully sued?"); Rosenberg, Contemporary Litigation in the United States, in Legal Institutions Today: ENGlish and American Approaches ComPARED 152, 162 (1977).

32. See generally Mause, supra note 16 , at 30.

33. See, e.g., D. DoBbS, supra note 14, § 7.3, at 528; W. ProsSER, HANDBOOK OF THE LAW OF ToRTS $\S 120$ (4th ed. 1971).

34. See, e.g., Weisman v. Middleton, 390 A.2d 996, 999 (D.C. 1978); W. Prosser, supra note 33, § 120, at 856; Annot., 21 A.L.R.3d 1068 (1968).

35. See, e.g., IDAHo R. CIv. P. 54(e)(1) (fee shifting if case "brought, pursued or defended frivolously, unreasonably or without foundation"); ILL. ANN. STAT. ch. 110, §41 (Smith-Hurd Cuin. Supp. 1982-1983) (fee shifting when allegations and demals "made without reasonable canse and found to be untrue").

36. See Mause, supra note 16 , at 30.

37. See id. 


\section{C. "Punitive" Fee Shifting.}

Punishment for unjustified or undesirable behavior-sometimes in the transaction giving rise to litigation and sometimes in connection with the bringing or conduct of the litigation itself-finds considerable acceptance as a reason to shift fees in certain situations. At least three analytically separable notions underlie this rationale. As with pumitive damages generally, a principal concern is deterrence of aggravated misconduct. This first strain is often coinbined with a second, imposing punishment on one guilty of sucl misconduct. ${ }^{38}$ Third, the misconduct (whether in or out of court) can cause either aggravated emotional hann or pecuniary loss in the forn of undeserved legal expenses; im sucll cases the justifications of punishment and compensation can coimcide. ${ }^{39}$ This section questions the extent to which punishment properly supports fee shifting, as opposed to assessments that need bear no necessary relation to legal costs. Be that as it inay, our law does often regard punishment as a basis for fee shifting.

The large inajority of the world's systems using general two-way fee shifting need not face the issue of punitive shifting for substantive wrongs because they already allow shifting on a broader basis. In the United States, the widespread rejection of both general indemnity and the make-wliole rationale as a basis for considerable one-way shifting leaves open the possibility of grounding some fee shifting on a rationale of punishment for conduct worse than mere negligence, breach of contract without bad faith, or other bases for conpensatory damages. The best example of fee shifting on such a basis is that in many states legal fees constitute a proper element of punitive damages. ${ }^{40}$ And in Georgia, to cite a different example, a statute provides for shifting in cases of bad faith breach of contract. ${ }^{41}$

The punitive rationale is also invoked to support fee shifting for abuse of legal process, both in the raising of baseless claims and defenses generally and in the use of unjustified tactics in the course of

38. See generally D. Dobes, supra note $14, \S 3.9$, at 204; J. GHIARDI \& J. KJRCHER, Punitive Damages law and Practice, ch. 2 (1981).

39. Punishment and compensation coincide when misconduct causes loss not compensated for on other grounds, as with the recovery of legal fees as an element of punitive damages. See infra text accompanying note 40 . Coinpensation stands alone-or in tandein with deterrence, but at any rate without an element our systein labels "punitive"-when behavior short of aggravated misconduct, such as negligence, inflicts loss. And punishment can be added on top of compensation, thus standing independently of it, when it takes the form of a purely punitive and deterrent assessment of smart money.

40. See Annot., 30 A.L.R.3d 1443 (1970).

41. See GA. Code ANN. § 20-1404 (1977). 
litigation. ${ }^{42}$ Perhaps the leading example of a fee shifting practice reflecting this idea is the federal courts' bad faith exception to the American rule for cases in which a party refuses to recognize a clear legal right or engages in bad faith conduct in litigation. ${ }^{43}$

Despite its currency as a basis for fee awards, only in certain situations does "punishment," as commonly understood, have any proper relationship to fee shifting. If misconduct in or out of court causes unnecessary legal expense not otherwise recompensed, "punitive" and make-whole concerns coincide and support shifting of the fees. In particular, fee awards to deter and compensate for the costs imposed by dilatory and harassing litigation tactics seem greatly underused im this country. ${ }^{44}$ But the amount of an adversary's legal fee often will not provide the full or optimal measure of deterrence and punishment. 45 Vexatious litigation, for example, not only runs up an adversary's legal bills; it also delays other people's cases and imposes a burden on the courts. Similarly, a plaintiff entitled to compensatory daunages will often imcur little or no extra expense in proving that his adversary's conduct was so outrageous as to support a punitive award. Hence, the amount of any punitive award should be determined independently of, or at least in addition to, any legal fee that may be incurred. Depending on the mix of concerns involved, fee shifting may not be the correct approach even when punishment for a litigant's conduct seems called for, and it may well be inappropriate to limit the sanction to the amount of fees incurred.

To whatever extent punishment justifies fee shifting, moreover, like the make-whole rationale it does not support general indemmity. 46 Presumably, we often do not want to deter good-faith pressing of tenable but not clear-cut claims and defenses, especially those turning on unresolved points of law or, im many instances, genuinely controverted factual disputes. No blame attaches to such litigation, and it does not call for strong deterrence. Any fee shifting against an unsuccessful party in such a situation should rest on grounds other than punishment or deterrence of litigation.

42. See generally, eg., Comment, supra note 25, at 652-53.

43. See Hall v. Cole, 412 U.S. 1,5 (1973) ("In this class of cases the-underlying rationale of 'fee shifting' is, of course, punitive"). See generally Note, Attorney's Fees and the Federal Bad Faith Exception, 29 Hastings L.J. 319 (1977). Solne states, by statute or decision, have similar policies. See id. at 332-35; see also, eg., Idaho and Illinois provisions quoted supra note 35.

44. See, e.g., Comment, supra note 25, at 652-53.

45. See Cordeco Dev. Corp. v. Santiago Vasquez, 539 F.2d 256, 263 (1st Cir.) ("Traditionally, punitive damages have been considered a more precise measure of a defendant's wrongful conduct than an award of fees."), cert. denied, 429 U.S. 978 (1976).

46. See Mause, supra note 16 , at 46. 


\section{D. "Private Attorney General" Theory.}

Litigation sometimes produces benefits beyond those reaped by the successful party. Such litigation furthers the public interest, or at least a private interest broader than that represented by the actual parties. Yet if the American rule applies in its full rigor, the cost to any private party of conducting the litigation inay well exceed any gains he can expect, even though the total gam to all beneficiaries may greatly exceed the costs. As a result, potential plaintiffs inay well refrain from bringing socially beneficial suits because the gains would not suffciently further their private interests.

When the success of a suit promotes a common fund in which the individual plamtiffs have a part interest, the fund serves as a handy source upon which to draw to spread the cost from the litigants to all the beneficiaries. ${ }^{47}$ Similarly, some courts have approved a "substantial benefit" theory supporting fee awards when they will spread the costs annong the mcidental beneficiaries of litigation. ${ }^{48}$ Though solnetimes viewed as forms of fee shifting, such recovery of fees from a common fund or spreading thein among beneficiaries does not amount to the kind of shifting considered in this article. Instead, it rests on a theory of sharing the cost ainong those aligned with the plaintiff rather than extractimg it from the defeated adversary. ${ }^{49}$ Such practices represent variations on the American rule rather than adoptions of Enghishstyle indemnity.

The same concern for private costs unaking socially desirable litigation uneconomical for any prospective plaintiff, however, can arise when success would neither proinote a common fund nor confer the sort of tangible benefit that could permit spreading of liability for fees. Cases raising this concern often seek to enforce a right deemed to have special social importance.50 They also frequently involve situations in which governmental authority or resources do not suffice to assure adequate public enforcement, or in which successful pressing of such claims will benefit numbers of other people (by deterring other violations, for exainple, or unaking new law). ${ }^{51}$ A good many courts and

47. See generally A. Miller, AtToRneys' Fees IN Class Actions $15-17$ (1980); Dawson, Lawyers and Involuntary Clients: Attorney Fees From Funds, 87 HARv. L. Rev. 1597 (1974).

48. See, e.g., Hall v. Cole, 412 U.S. 1, 4-9 (1973); Serrano v. Priest, 20 Cal. 3d 25, 38-42, 569 P.2d 1303, 1309-12, 141 Cal. Rptr. 315, 321-24 (1977); A. MILLER, supra note 47, at 17.

49. See House Hearings, supra note 24, at 46 (testimony of Prof. C. Dallas Sands).

50. See, eg., CAL. Civ. Proc. Code $\S 1021.5$ (West 1980) (fee awards to prevailing parties in certain actions that result "in the enforceinent of an important right affecting the public interest").

51. See Hermann \& Hoffmann, Financing Public Interest Litigation in State Courts: A Proposal for Legislative Action, 67 CoRNELL L. REv. 173, 195-96 (1978) (draft "private attorney general" statute focusing on absence of sufficient econoumic incentive for individual litigants plus substan- 
legislatures have responded to such cases by authorizing fee shifting on a "private attorney general" theory to a party who successfully brings such an action. Though the Supreme Court has prevented federal courts from shifting fees on this basis in the absence of an authorizing statute, ${ }^{52}$ Congress has indeed enacted several such laws, most notably the Civil Rights Attorney's Fees Awards Act of 1976. ${ }^{53}$ Similarly, the California Supreine Court has approved the private attorney general fee shiftimg doctrine as a matter of decisional law. ${ }^{54}$ Whatever difficulties may arise in the administration of the doctrine,,$^{55}$ the basic rationale for having someone other than the successful plaintiff bear at least the share of the legal expenses beyond that related to plaintiff's own benefit seems sound. 56

\section{E. Affecting Relative Strengths of Parties.}

When one side in a particular type of higation regularly has the advantage of superior resources, holding out the prospect of reimbursement of fees can improve the position and stiffen the resolve of the

tial public benefit). See generally Nussbaum, Attorney's Fees in Public Interest Litigation, 48 N.Y.U. L. REv. 301, 305 (1973).

52. Alyeska Pipeline Serv. Co. v. Wilderness Soc'y, 421 U.S. 240 (1975).

53. 42 U.S.C. $\$ 1988$ (Supp. IV 1980).

54. See Serrano v. Priest, 20 Cal. 3d 25, 42-47, 569 P.2d 1303, 1312-15, 141 Cal. Rptr. 315, 324-27 (1977) (at least for rights claimed under state constitution); $c f$. County of Ada v. Red Steer Drive-Ins, Inc., 101 Idaho 94, 100-01, 609 P.2d 161, 167-68 (1980) (applying Serrano standards for attorney fee award on private attorney geueral theory and denying award after finding standards not met, without stating fee award would follow if standards were met).

55. See, eg., Alyeska Pipelinc Serv. Co. v. Wilderness Soc'y, 421 U.S. 240, 263-64 (1975) (problems in determining which laws are important enough for doctrine to apply, standards for awards, etc.).

56. The question remains whether to burden the defendant or the public treasury. See infra text accompanying note 102.

A theme sometimes related to the private attomey general rationale has been a desire to provide broad and effective remedies for violation of important rights. See, e.g., Comment, Attorney's Fees in Damage Actions Under the Civil Rights Attorney's Fees Awards Act of 1976, 47 U. CHI. L. REv. 332, 343 (1980). This rationale of favoring important rights, though it possesses considerable intuitive appeal, may have little, if any, meaning independent of one or inore other bases for fee shifting. First, it may reflect a sense that violations of a particular kind of right make full compensation especially appropriate. Second, it may reflect a desire to increase deterrence to all violations of a right through fear of greater recoveries. Third, it may reflect a felt need for special incentives to encourage the bringing of suits, perhaps becanse many claims of a certain type-as in civil rights actions-are hard to compensate for monetarily and inay yield only nominal or nonmonetary relief. Finally, it may also reflect the idea behind the "private attorney general" doctrine: litigation to cnforce a right benefits the public beyond the relief to the plaintiff, so that the plaintiff should not have to bear the full cost of the proceeding lest there be too little enforcement of the right. 
relatively weaker side..$^{57}$ In many types of litigation, of course, no regular imbalance may occur, regardless of the disparities that arise in individual cases. Much general tort and contract litigation probably falls into this category. But when a legislature perceives a regular imbalance, it can seek to match adversaries nore evenly by adopting some form of fee shifting to prevent disproportionate advantage in access to and use of the legal process. Congress appears to feel that one category of sucl cases is that im which the federal government opposes an individual without considerable wealth or a concern of small to inoderate size. Senator Dennis DeConcimi explained the recently-enacted Equal Access to Justice Act ${ }^{58}$ as focusing on those "for whoin cost may be a deterrent to vindicating their rights." 59 The statute provides for fee shifting in favor of certain private parties who prevail in nontort civil actions and administrative proceedings against the federal government, when the government cannot satisfy the tribunal that its position was substantially justified or that other special circumstances, such as testing of a novel legal theory, make a fee award unjust. ${ }^{60}$

One other class of cases in which Congress has provided for oneway fee shifting illustrates the regular-imbalance situation, whether or not Congress had that concern in mind in including provision for fee shifting. In hitigation for dainages under the federal minimum wage, maximum hours, and sex discrimination in wages statutes, ${ }^{61}$ which will normally involve einployees litigating against their much betterfinanced employers, courts must allow "a reasonable attorney's fee to be paid by the defendant" 62 to a prevailing plaintiff. ${ }^{63}$

57. See Aronson, Attomey-Client Fee Arrangements: Regulation and Review, 68 A.B.A. I. 284, 287 (1982); $c$. Mause, supra note 16, at 44 (including, among factors usable to identify situations suitable for fee shifting, whether defendants in a class of cases are usually institutional).

58. Equal Access to Justiee Act, Pub. L. No. 96-481, 94 Stat. 2325 (codified in scattered sections of 5, 28 U.S.C.).

59. DeConcini, Equal Access to Justice, 2:6 Fed. ATTY. Fee Awards REP. 3, 3 (Oct. 1979); see also Equal Access to Justice Act, Pub. L. No. 96-481, tit. II, \& 202(a)-(b), 94 Stat. 2325 (1980) (findings that smaller litigants "may be deterred frown seeking review of, or defending against, unreasonable governmental action because of the expense" and that government lias "greater resources and expertise").

60. See DeConcini, supra note 59, at 4; 5 U.S.C. $\$$ 504(a)(1) (Supp. IV 1980) (administrative proceedings); 28 U.S.C. $\$ 2412$ (d)(1)(A) (Supp. IV 1980) (nontort civil actions).

61. 29 U.S.C. $\$ \S 206-207$ (1976).

62. 29 U.S.C. $\$ 216$ (b) (Supp. IV 1980). The fee shifting provision, from section 16 of the original Fair Labor Standards Act of 1938, ch. 676, 52 Stat. 1069 (1938), appears to have become part of the Act by the initiative of a conference committce that left no recorded explanation of its purpose. See 83 CONG. REC. 9246-55 (1938) (conference report summarizing prior House and Senate bills, setting out conference committee version, and explaining new draft without mentioning fce shifting provision).

63. See also J. Lorenz \& B. Hunter, Fimancing Private Enforcenent Through Statutes Authorizing Awards of Attorneys' Fees 18-19, $20-21$ (1979) (unpublished paper for Council for Pub- 
The use of fee shifting to affect the balance of resources in litigation need not have as its only end the equalization of party strengths. Senator DeConcini's statement in support of the Equal Access to Justice Act touched upon several other themes alluded to in this discussion, including "making whole those who have been the victims of unreasonable government action,"64 encouragement of citizens' resistance to governmental actions they feel unreasonable, ${ }^{65}$ generation of public law precedent, ${ }^{66}$ and deterring agencies from oppressive and abusive hitigation. ${ }^{67}$ The bill nay have embodied a considerable antiregulatory animus as well, though it was modified to eliminate a provision for automatic shifting and to substitute the "not substantially justified" criterion after expressions of concern about the chilling effect of automatic shifting on government enforcement efforts. ${ }^{68}$

\section{F. Economic Incentives Generally.}

The foregoing discussions have touched upon the incentives for hitigants created by various forms of fee shifting, but have not begun to exhaust the subject. Fee shifting is generally believed to have a number of effects on litigant behavior at many points in the bringing and conduct of a case, although in the present state of knowledge the direction and strength of the effects are often the subject of inuch speculation and uncertainty.

The fee shifting system in effect seems likely to affect decisions whether to pursue legal relief and whether to settle or resist a claim pressed by another. Among the inost widely accepted hypotheses on fee shifting are that two-way shifting, as coinpared with the American rule, would encourage the pursuit of meritorious small claims ${ }^{69}$ and

lic Interest Law) (mentioning federal and state fee shifing statutes applicable in other situations likely to involve parties with unequal resources) (paper on file in author's office at Duke Law School).

Two-way fee shifting can also remedy regular imbalances in appropriate circumstances. California, Oregon, and Washington, apparently perceiving imbalance not from the involvement of a particular institutional litigant or a usual relationship between plaintiffs and defendants but froun one-sidedness in contracts, have statutes providing for two-way fee shifting whenever a contract specifies a one-way shift. Cal. CIv. CODE \& 1717 (West Supp. 1982); OR. Rev. Stat. § 20.096 (1981); WaSH. REv. CODE ANN. $\$ 4.84 .330$ (West Supp. 1982). See generally Comment, Attorney's Fees and Civil Code 1717, 13 PAC. L.J. 233 (1981).

64. DeConcini, supra note 59, at 3.

65. See id.

66. See id.

67. See id. at 3,4.

68. See id. at 4.

69. See, eg., Ehrenzweig, Reimbursement of Counsel Fees and the Great Society, 54 CALIF. L. Rev. 792, 796 (1966). 
discourage weaker ones through the threat of adverse shifting. ${ }^{70}$ Much speculation also exists about whether two-way fee shifting would raise or lower the overall level of hitigation. Given the mixture of encouraging and discouraging incentives, varying levels of risk preference annong litigants, and different amounts involved, it seems impossible to propose any general hypothesis on this question. Similarly, a host of possible effects on the rate, timing, and level of settlements may occur. $^{71}$

The desire to achieve certam effects through the use of incentives often overlaps with a perception that certam fee shifting ineasures will serve the ends of equity. The standard of Christiansburg Garment Co. v. $E E O C$ for shifting against a losing civil rights plaintiff if the claim was "frivolous, unreasonable, or without foundation," "72 for exainple, seems well calculated to deter the pressing of such claims. But it also satisfies a human urge to make such a litigant feel the consequence of his conduct whether he lets himself be influenced by such deterrents or not, as well as to make the defendant whole for having to conduct what should have been an unnecessary defense.

\section{Implications of the Rationales}

It is a commonplace of legal inethod that the reasons for a policy's adoption should guide its apphication in difficult cases. Decisions and inuch commentary on fee shifting often attempt to observe this inaxim, ${ }^{73}$ but to a significant extent there have been failures to inaintain the connection between purpose and application. ${ }^{74}$ Moreover, there has been no systenatic effort to discuss the range of possible implications of the various rationales. This part of the article tries to identify as. many different general types of implications as possible, though it does not attempt to pursue every possible implication of every conceivable rationale. Rather, it atteinpts to illustrate that the range of implications is broader than has been generally recognized and to show the feasibility and possible significance of unore systematic reasoning

70. See, e.g., Comment, Award of Attorney's Fees in Alaska: An Analysis of Rule 82, 4 UCLAALASKA L. REV. 129, 162-63 (1974).

71. See generally Shavell, Suit, Settlement, and Trial: A Theoretical Analysis Under Alterna. tive Methods for the Allocation of Legal Costs, 11 J. LEGAL STud. 55 (1982). I attempt, in a study to follow, to develop a set of specific hypotheses for differing types of effects under various circumstances. See Rowe, 46 LAW \& GONTEMP. ProBS. (1983) (forthcoming).

72. 434 U.S. 412,421 (1978).

73. For example, see cases and commentary discussed infra in text accompanying notes 8287; Note, Pro Se Can You Sue? Attorney Fees for Pro Se Litigants, 34 STAN. L. REv. 659 (1982).

74. See, e.g., supra text accompanying notes $40-45$ (describing questionable use of punitive rationales to support fee shifting). 
about fee shifting. The implications are of three basic sorts: whether in a class of cases or a particular case to award fees to the winner; against whoin to assess a fee to be awarded; and how much to award.

\section{A. Whether to Shift Attorney Fees.}

Once a rationale has been accepted as sufficient reason to award attorney fees to a prevailing party, ${ }^{75}$ it can have various kinds of implications for the systeen's approaches to decisions concerning whether to shift fees. First, it can point to one or another general type of fee shifting scheme or can suggest award or denial of fees in an individual case depending on its particular facts. Second, the reason for a fee shifting rule has implications for whether and to what extent courts should have discretion in decisions whether to award fees, including the problem of fee awards in close cases.

1. General Approaches and Awards in Individual Cases. A decision that an end is worth pursuing by the use of fee shifting need not dictate the choice of a general two-way shifting rule of the sort followed in most of the developed Western world. As Congress has recognized whon favoring certain important rights, espousing the "private attorney general" idea, or attempting to equalize regular imbalances between adversaries, a policy of one-way shifting in favor of prevailing plaintiffs in specific types of actions better achieves those ends. ${ }^{76}$

75. My primary aim in this article is to analyze the several rationales for attorney fee shifting and to explore their implications, not to prescribe whether one or another rationale is sufficiently persuasive to adopt some form of fee shifting system. Obviously, the relative appeal of one or more rationales must be weighed in a threshold decision whether a system should engage in fee shifting at all, as against countervailing concerns such as excessive encouragement or discouragement of litigation and the "transaction costs" of deciding whether to shift fees in an individual case and if so low much to award. My evaluation of particular rationales as more or less persuasive on their own is not to imply whether they should suffice as reasons to adopt fee shifting when considered in context with other factors.

76. The persuasiveness of the rationale for a basically one-way fee shifting rule in civil rights cases appears to be surprisingly widely accepted in Congress. While proposing several measures to limit fee awards in federal civil rights cases, Senator Orrin Hatch nonetheless strongly endorsed the fundamental idea of fee award standards more favorable to plaintifis than to defendants:

Some State and local government officials have suggested that a fairer approach, and one which would deter friv[o]lous suits, would be to allow plaintiffs and defendants to recover equally.

The legislative history of the 1976 Fees Act pointed out clearly, and correctly I think, the need for the dual standard: If the persons seeking to enforce their civil rights were faced with paying their opponents[] attorneys' fees if they simply did not win the case, the Fees Act would create a greater disincentive to bring these civil rights suits than the situation it attempted to remedy.

128 CONG. REC. S4878 (daily ed. May 11, 1982).

For an unusual reverse twist proposing one-way shifting in favor of prevailing defendants to combat harassing lawsuits, see Brill, Loser Pays All, AM. LAw., July 1980, at 5; Brill, You Win but You Lose, N.Y. Times, July 2, 1980, at A27, col.1. The proposal overlooks the possibility of 
Indeed, what is striking on examination of the various rationales is the relative weakness of the support for general indemnity. Of the rationales canvassed in the first part of this articlc, only two-the sense that general indemnity is simply just and, possibly, desirable overall incentives-justify general two-way shifting. ${ }^{77}$ The questionable coherence of the arguinent for general indemnity suggests, at the very least, that a general two-way shifting rule should be subject to important exceptions. ${ }^{78}$

In addition to affecting broad choices of overall approach, fee shifting rationales can affect narrower decisions about shifting in particular types of cases. This article has suggested that the rationale of inaking a wronged party whole supports shifting only when it supplies a basis for substantive rehef as well (chiefly in suits for compensatory dainages) or when the bringing, conduct, or continuation of an action ainounted to a legal wrong. ${ }^{79}$ Such a basis for fee shifting would support fee awards to prevailing plaintiffs across a fairly broad range of ordinary litigation, though not in actions for restitution. ${ }^{80}$ But differing fce shifting rationales inay coexist, and the limits on the reach of the make-whole rationale need not set the outer bounds for situations in which shifting might occur. Restitution, for example, is often appropriate because of a breach of faith on the part of the defendant. ${ }^{81} \mathrm{~A}$ concern for deterring and punishing such misconduct could readily support awards in such cases beyond disgorgement of the amount by which defendant had been unjustly enriched.

To give a final and inore particularized example, a current split in the circuits illustrates how different rationales for fee shifting can affect decisions concerning whether to award fees in individual cases. The Courts of Appeals for the Second ${ }^{82}$ and Ninth ${ }^{83}$ Circuits view the 1976 Civil Rights Fee Awards Act as an expression of congressional intent to encourage cases that confer benefits on others and the bringing of civil rights enforcement suits. Under this view, when a civil rights plaintiff

combating harassment by awarding fees only on a finding of harassment, not to mention the danger of deterring meritorious claims as well as frivolous ones.

77. A concern for simplicity and predictability could justify a flat two-way shifting rule. $C f$. R. Schlesinger, Comparative Law: CASEs-Text-Materials 688 (4th ed. 1980) (Continental preference for broad rules). It could just as well support exceptionless application of the American rule and, in any event, appears in this country to have taken second place to efforts at more discriminating applicatious.

78. See supra notes $22-25$ and accompanying text.

79. See supra text accoinpanying notes 33-36.

80. See supra text accoinpanying note 30.

81. See D. DoBsS, supra note $14, \S 4.1$, at 222.

82. See Zarcone v. Perry, 581 F.2d 1039 (2d Cir. 1978), cert. denied, 439 U.S. 1072 (1979).

83. See Buxton v. Patel, 595 F.2d 1182 (9th Cir. 1979). 
has a strong, substantial damage claim that makes no significant contribution to precedent, he needs little or no extra encouragement to bring his claim and may not qualify for a fee award. A different reading of the legislative history emphasizes Congress' apparent concerns for broad and effective remedies ${ }^{84}$ and enhanced general deterrence of civil rights violations. ${ }^{85}$ From such a view of the purposes of the rule would follow a willingness to allow fee awards even when they do not seem needed to encourage plaintiffs to sue, a position adopted by the Court of Appeals for the First Circuit ${ }^{86}$ and supported by a recent student commentary. 87

2. Judicial Discretion and the Close-Case Problem. Existing fee shifting statutes and rules often provide for the exercise of judicial discretion whether or not to award fees. ${ }^{88}$ There can be arguments over whether discretion excessively waters down the use and desired effects of shifting and threatens too much appeal-generating uncertainty, ${ }^{89}$ or whether it is essential to avoid injustice in imdividual cases. ${ }^{90}$ Such general considerations play an appropriate role in decisions on whether

84. See Comment, supra note 56, at 343 (quoting materials from legislative history).

85. See id. at $347-49$.

86. See Sargeant v. Sharp, 579 F.2d 645 (1st Cir. 1978).

87. Comment, supra note 56.

A different and unfortunate sort of argument over whether to award fees in a class of cases can arise when an applicable rule, such as Federal Rule of Civil Procedure 68 on offers of judgment, refers to "costs" and an applicable statute provides for an award of fees without clarifying whether fees are to be treated as "costs" for purposes of the rule. Compare, e.g., Delta Air Lines v. August, 450 U.S. 346, 363 (1981) (Powell, J., concurring in result) ('the 'costs' component of a Rule 68 offer of judgment in a Title VII case must include reasonable attorney's fees accrued to the date of the offer"), with id. at 377 (Rehnquist, J., dissenting) (nothing suggests that Congress in the civil rights statutes "intended to amend Rule 68 by adding attorney's fees to otherwise taxable 'costs' under that Rule"). In fee shifting statutes Congress generally refers to fees as part of "costs," see Note, Rule 68: A "New" Tool for Lutigation, 1978 DUKE L.J. 889, 899, but without apparent consideration whether fees should be treated as "costs" for all purposes. Congress and the legislatures could help by addressing this question directly when adopting fee shifting statutes; in the absence of specific direction, some courts may feel obligated to treat fees as "costs" generally despite what may have been unconsidered use of the term. See id. Courts not feeling so constrained, and legislators in drafting statutes, can refer back to the purposes underlying a fee shifting scheme in dealing with such peripheral but still significant matters. See generally Note, Offer of Judgment and Statutorily Authorized Attorney's Fees: A Reconciliation of the Scope and Purpose of Rule 68, 16 GA. L. REv. 482 (1982).

88. See, eg., 42 U.S.C. $\$ \S 1988$ (Supp. IV 1980), 2000e-5(k) (1976) (court may allow fee award "in its discretion". to prevailing party); FED. R. CIv. P. 37(a)(4) (award of expenses, including attorney fees, to prevailing party on discovery order motion, "unless the court finds that [the losing side's position] was substantially justified or that other circumstances make an award of expenses unjust").

89. See, e.g., Note, Promoting the Vindication of Civil Rights Through the Attorney's Fees Awards Act, 80 CoLuM. L. Rev. 346, 351-52 (1980).

90. See, eg., Wills \& Gold, Attomeys' Fees in Litigation: Time to Discard the American Rule?, 4:3 Litigation 31, 60 (Spring 1978). 
and how much to leave room for discretion, but so should the underlying rationale of a fee shifting policy.

If making a wronged party whole for substantive legal injury underlies a fee shifting policy, discretionary denial of a fee award is unwarranted once the decision has been made to grant coinpensatory relief. ${ }^{91}$ Presumably, the court has no discretion to deny compensation for doctors' bills; a general decision to include attorney fees in coinpensatory damages would place the two costs on the same footing. If the rationale is general deterrence, that also seems to support mandatory fee awards ${ }^{22}$ or at least gives reason to inake the standard for the exercise of discretion lean strongly in the direction of not denying a shift. ${ }^{93}$ In contrast, the desire to deter unjustified pressing of or resistance to claims, defenses, or steps in litigation seems to deinand solne scope for the exercise of discretion to measure the reasonableness of the losing party's conduct and make no award if that conduct was reasonable. ${ }^{94}$

One of the problems of a system of general fee shifting, and one that can make judicial discretion to deny fee awards appear especially attractive, is that applying the rule can seem liarsh and unfair in close cases. ${ }^{95}$ And difficult cases, with outcoines hard to predict, seen more likely to end in an expensive trial than in a settlement. Close cases may thns cast the loser assessed for fees in the role of one unfairly and severely pumished for proceeding entirely reasonably. Though he may have lost, he acted not ouly within his rights but with good foundation in contesting the case.

The extent to which the close-case conundrum is properly regarded as a problem depends on the reasons behind a fee shifting policy. The English, with their general indemnity rule and its shaky theoretical underpinnings, have good reason to feel uncomfortable with some of its applications. But if equity to a prevailing party through nake-whole compensation underlies a particular fee shifting rule, the

91. Considerable scope for judicial decision on what amount should reasonably be awarded as attorney fees could appropriately remain. There needs to be some constraint on litigants' likely tendency to spend freely if they can expect to receive full reimbursement.

92. See, e.g., 29 U.S.C. \$ 216(b) (Supp. IV 1980) (minimum wage, maximum hour, and sex discrimination in wages claims) (court "shall" award reasonable attorney's fee to prevailing plaintifi).

93. See, e.g., Christiansburg Garment Co. v. EEOC, 434 U.S. 412, 416-17 (1978) (shifting in favor of prevailing plaintiff under various civil rights statutes "unless special circumstances would render such an award unjust" ") (quoting Newman v. Piggie Park Enters., 390 U.S. 400, 402 (1968)).

94. See, e.g., FED. R. CIV. P. 37(a)(4), quoted supra in note 88.

95. See, e.g. FINAL REPORT, supra note 23, at 235; Leggatt \& Williams, Contemporary Litigation in England, in LEgAL INSTITUTIONS TODAY: ENGLISH AND AMERICAN APPROACHES COMPARED 185, 190 (1977); Rosenberg, supra note 31, at 167-68. 
grounds for being troubled by the close-case difficulty disappear. With a make-whole theory as the basis for fee shifting, a fee award in a close case should create no more discomfort than the rest of a damage award-unless we really want de facto compromise verdicts in such cases. Once granted inake-whole relief, a party should get full compensation whether the initial decision seems easy or hard. 96

Similar considerations apply, though perhaps with some attenuation, when the concern behind fee shifting is the external effect of general deterrence; the question would be whether the reduction in apparent inequity to a reasonable loser justifies the reduction of any deterrent effect from denying shifts in close cases. And when the external effect in question is the benefit of test litigation, different considerations may govern because we may want neither side deterred by the threat of adverse shifting.

Only if a fee shifting rationale focuses on the party who may be required to pay fees, such as administering punishinent for unjustifiable bringing of or resistance to litigation, should there be discomfort in shifting fees generally in close cases. In such a case, these kinds of rationales do not apply: the defendant acted reasonably and, given the closeness of the case, represents neither a desirable target for deterrence nor one likely to be deterred. Consequently, if such loser-focused rationales are the basis for a fee shifting policy, close cases would be appropriate ones for denial of fee awards. ${ }^{97}$

To put the argument in general terms, to the extent that justifications for a fee shifting rule focus elsewhere than on equity and incentives to the losing party, the close-case unease becomes irrelevant to decisions concerning whether to shift fees in a given case. Most of all, with make-whole relief the focus is so clearly on justice to the wronged party that an understandable solicitude for a loser who reasonably contested the proceeding appears to have no proper role.

96. One commentator suggests that it might be more acceptable to award fees in property damage cases than in "personal imjury cases where the imprecision of the measure of damages prevents this kind of itemization of what the judgment covers from being very meaningful." $C$. Sands, An Agenda Through Which to Address the Advisability of Liberalizing the Rules Governing Awards of Attorneys' Fees to Prevailing Litigants 9 (1976) (memorandum for ABA Consortium on Legal Services and the Public). Politically, the point may prove accurate. Logically, however, it is hard to see why imprecision in one measure of damages should provide reason to ignore another aspect of damages that can be assessed more exactly.

97. Limiting pumitive or deterrent fee shifting to clear-cut cases eases another aspect of the close-case problem-the nagging feeling that we may compound injustice to the loser because of the significant chance that the court was wrong on the merits of the case. See, e.g., Satterthwaite, Increasing Costs to Be Paid by Losing Party, 46 N.J.L.J. 133, 133, 135 (1923). To the extent that shifting takes place only in cases involving abuse, the likelihood of its being associated with judicial error declines sharply. 
B. Source of the Fee Award.

The reasons for a fee shifting policy can liave implications as well for the question "froin whom"? Most commonly, liability for a shifted fee falls on the losing party. In the large inajority of cases, that is only sensible. If compensation as part of general inake-whole relief justifies a fee award, the amount should come from the same person liable for the rest of the compensation. Similarly, much of the time the person deserving punishment or whose conduct in litigation merits deterrence will be the out-of-court wrongdoer or the party who bears ultimate responsibility for the conduct of the litigation. But blame nay also attach to the lawyer, if he was responsible for the objectionable behavior. Solne provisions therefore permit or direct that the paynent come from the lawyer: 98

When the reasons for a fee shifting policy have to do with external effects, the implications for who should be the source of fee payinents are less obvious. Both sides contribute to the process of generating useful precedent. Though we want to reward the winner for performance of a useful social function, it does not seem desirable to create a deterrent by taking fees froin the loser, especially because valuable test litigation often simply reconfirms an old rule. In theory, then, there is a strong case for paying the fees of at least the prevailing party in test cases from public funds. ${ }^{99}$ Given frequent uncertainty over likely outcolne and the usefulness of the service rendered, moreover, there is considerable appeal to the idea of having the state reimburse both sides. The Australian state of New South Wales maintains a Suitors'

98. See, e.g., 28 U.S.C. \& 1927 (Supp. IV 1980) (attorney who "multiplies the proceedings in any case unreasonably and vexatiously may be required by the court to satisfy personally the excess costs, expenses, and attorneys' fees reasouably incurred because of such conduct"); FED. $R$. Civ. P. 37(a)(4) (attorney advising conduct on discovery order inotion listed among persons who, may be ordered to pay prevailing side's fees).

99. Cf. Walker, Court Awarded Attorney's Fees Under the Private Attorney General Concept: A Defense Perspective, 23 U. KAN. L. REv. 653, 678 (1975) (for public payment of fees of prevailing plaintifis in public interest suits); House Hearings, supra note 24, at 67 (question by counsel raising possibility of governmental payment of fees of prevailing private litigant who acted to enforce governmental policies).

The federal courts have interpreted two federal statutes applicable to review of agency action-the Toxic Substances Control Act, 15 U.S.C. \$ 2618(d) (1976), and the Clean Air Act, 42 U.S.C. $\$ 7607$ (f) (Supp. IV 1980)-as permitting fee awards even to losing parties in appropriate cases. See generally Environmental Defense Fund v. EPA, 672 F.2d 42 (D.C. Cir. 1982); Sierra Club v. Gorsuch, 672 F.2d 33 (D.C. Cir. 1982), petition for cert. filed, 51 U.S.L.W. 3121 (U.S. Aug. 11,1982 ) (No. 82-242). Congress can legitimately seek to encourage early interpretation of new statutes and their enforcement in the public interest. See id. at 35-36 (quoting H.R. REP. No. 95294, 95th Cong., 1st Sess. 337 (1977), and Natural Resources Defense Council v. EPA, 434 F.2d 1331, 1338 (1st Cir. 1973)). But if the same reasoning were to be extended to private litigation, the unfairness of taking the fee from the vindicated winner would make the case for public financing even stronger than in test cases generally. 
Fund that provides some reimbursement for lawyers' fees of both sides in successful appeals on questions of law, 100 and reform studies in Britain have considered the idea of having the government pay the legal fees of both sides in cases raising points of law of major public importance. ${ }^{101}$ Absent such funding, the desirability of test litigation suggests that any fee shifting policy adopted for such cases should be designed to have the least possible deterrent effect.

In other public benefit situations, such as injunctions with widespread effect or the general deterrent effect on prospective defendants of encouraging plaintiffs with certain types of claims through reimbursement for their fees if they win, the reasons for sparing losing defendants from fee shifting are not so strong. True, inuch of the public benefit may come from effects on coinplete strangers to the litigation; but it can be important to effective deterrence to show by example that violators will bear the victims' enforcement costs. Moreover, the defendants are members of the class of violators and of those whose conduct deserves deterrence; economic sense dictates placing the cost of enforcement at least on the sector whence caine the violations. Because it would normally be unfair, uneconomical, and impractical to collect from those other members of the sector not involved in the particular violation, good reason exists in this sort of "private attorney general" case to place the cost of enforcenent, notwithstanding the public benefit, on the violator. ${ }^{102}$

\section{Amount of Fee Award.}

The final general type of implication of fee shifting rationales goes to how much should be awarded. First, straddling the "from whom" and "how inuch" issues is the question of whether a losing defendant should have to pay a "contingency bonus" for the plaintiff's lawyers who assumed the risk of not being paid in case of defeat. Second, the reasons for a fee shiftimg rule can generally affect approaches to the calculation of fees to be shifted.

1. Source of Increased Payment for Contingency Risk. Systems with general two-way fee shifting commonly ban contingent fees. ${ }^{103} \mathrm{It}$

100. See Suitors' Fund Act, 1951, 10 N.S.W. STAT. 729 (1824-1957 \& Perm. Supps. 1958-1966, 1967-1971, \& Supp. 1972-1977).

101. See Final Report, supra note 23, at 219-21, 224; Justice, Claf: Proposals for a CONTINGENCY LeGAL Aid FUnd 22 (1978).

102. See Christiansburg Garment Co. v. EEOC, 434 U.S. 412,418 (1978); Aronsou, supra note 57, at 287; Leubsdorf, The Contingency Factor in Attorney Fee Awards, 90 YALE L.J. 473, 490 (1981); Mause, supra note 16, at 45. But see supra note 99.

103. See, e.g., W. Ffennigstorf, The European Experience in Legal Expense Insurance, in LEgal Service Plans: Approaches to Regulation 487, 508-09 (1977). 
is sometimes assumed that such fee shifting is incompatible with contingent fees, ${ }^{104}$ which finance inuch plaintiffs' damage litigation in this country. Yet nothing about fee shifting makes contingent fee arrangements impossible. Plaintiffs and their counsel could agree on payment only in the event of victory, perhaps with provision for additional payment from the plaimtiff in case the fee assessed against the loser did not compensate the lawyer for his time and risk. ${ }^{105}$ Alaska in fact retains contingent fees while following general two-way shifting, ${ }^{106}$ as do some Canadian provinces. ${ }^{107}$ Moreover, the mostly one-way pro-plaintiff shifting provisions increasingly common in this country can readily coexist with contimgent fees.

Thus, even with broader fee shifting, contimgent fee arrangements could-and, given American legal traditions, very likely would-survive. ${ }^{108}$ But to make such arrangements economically viable (assuming lawyers take some cases that are not sure winners), compensation in winning cases must generally yield greater sums than conventional hourly rates would justify in order to make up for uncompensated time spent on losing ones. ${ }^{109}$ Fee shifting poses the problein whether the

104. See, e.g., Derfner, The True "American Rule": Drafling Fee Legislation in the Public Interest, 2 W. NEW ENG. L. REv. 251, 258 (1979); Leggatt \& Williams, supra note 95, at 194-95.

105. See Sands, An Expository Comment-On the Consortium's Proposal in Regard to Recovery of Attorney Fees by Prevalling Parties, 4:3 Alternatives 3, 4 (July 1977); White, Contingent Fees: A Supplement to Legal Aid?, 41 MoD. L. REv. 286, 296 (1978).

106. See Comment, supra note 70, at 146 n.109.

107. See Cooper \& Kastner, Access to Justice in Canada: The Economic Barriers and Some Promising Solutions, in 1 ACCESS TO JUSTICE 247, 259 (1978).

Two-way shifting does pose problems for contingent fee arrangenents, because one of their main attractions for plaintiffs is the absence of any substantial down-side risk. With two-way shifting, either the plaintiff risks having to pay the other side's lawyer (even if he does not risk paying his own) or his lawyer can assume the risk. But the problem of down-side risk arises under two-way shifting whether a particular fee arrangement is contingent or not.

Under present standards of professional ethics, lawyer assumption of ultimate liability for a shifted fee would be a disciplinary violation. See MODEl CODE OF Professional ResponsibiL. ITY DR 5-103(B) (1980). The recently proposed ABA Model Rules of Professional Conduct, however, would permit lawyer financing of civil litigation expenses with "repayment . . . contimgent on the outcome of the matter." Model Rules of Professional Conduct Rule 1.8(e)(1) (Proposed Final Draft 1981).

108. See Mause, supra note 16 , at 52 .

109. See R. POSNER, supra note $16, \$ 21.8$, at $448-49$. In ordinary litigation in this country the increase, or "coutingency bonus," commonly comes from basing the fee amount on a percentage of the dainage award obtained. Other formulas may also be used, such as unultiplying a time-rate figure by a factor related to the approximate level of risk, see Berger, Court Awarded Attorneys' Fees: What Is "Reasonable"?, 126 U. PA. L. REv. 281, 326 (1977), or adopting a general multiplier factor calculated to provide a desirable level of incentive, see Leubsdorf, supra note 102, at 474, 501-12. 
loser should have to pay for this "contingency bonus" in addition to the winning lawyer's time spent on the particular case. ${ }^{110}$

There is a strong initial argument against taking any contingency bonus from a losing defendant. In principle, a plaintiff could choose a noncontingent arrangement and assure the lawyer of payment regardless of the outcome, as defendants generally do. The lawyer would have no claim to a contingency bonus, and awarding one to the plaintiff in the event of victory would overcompensate the plaintiff. With no grounds to award a contingency bonus in such a case, treating the defendant differently simply because the plaintiff chooses a different financing arrangement with his lawyer seems unjust. If the plaintiff wants insurance against expenses in case he loses, he should have to pay his "insurer"-the lawyer taking the financial risk of defeat. Any fee amount shifted, on this argument, should cover only lawyer effort reasonably expended on the case, leaving further risk compensation a matter between lawyer and client. ${ }^{111}$ Saddling the defendant with anything more would be unfair. ${ }^{112}$

Despite the force of this argument, inuch current case law ${ }^{113}$ and commentary ${ }^{114}$ support the inclusion of a contingency bonus in fee awards, which suggests a need to explore possible justifications for doing so. The rationale of compensation for loss as the basis for fee shifting provides no foundation for contingency bonus awards from defendants. A winning plaimtiff receives full compensation, according to the argument advanced above, if he receives an award for his injuries and indemmity for the cost of lawyers' effort reasonably expended

110. Fee shifting can even compound this problem because it makes contingent arrangements conceivable in types of cases in which such arrangements are not viable without a shift. Because the plaintiff's recovery provides the source of a contingent fee under the American rule, actions for nonmonetary relief such as injunctions cannot be conducted on a contingent fee basis. Shifting would provide a possible source for a prevailing party's fee in such cases. See Comment, supra note 25 , at 709 .

111. See Sands, supra note 105, at 4. For an example of a lawyer-client arrangement taking account of the possibility of a favorable fee award, see Neely v. City of Grenada, 624 F.2d 547, 551 n.4 (5th Cir. 1980) (attorney-client contract providing for fee of greater of fee award or onethird of settlement). The court rejected an argument that it should, on the basis of the contract, limit its fee award to one third of the settlenent amount. See id.

112. See Donin, England Looks at a Hybrid Contingent Fee System, 64 A.B.A. J. 773, 774 (1978); White, supra note 105, at 296.

113. See, e.g., Northcross v. Board of Educ., 611 F.2d 624, 643 (6th Cir. 1979) (approving upward adjustment for risk of no compensation), cert. denied, 447 U.S. 911 (1980); Lindy Bros. Builders, Inc., v. American Radiator \& Standard Sanitary Corp., 540 F.2d 102, 117 (3d Cir. 1976) (same); Leubsdorf, supra note 102, at 473 n.l (citing cases in seven circuits and some states approving contingency bonus awards).

114. See, e.g., Berger, supra note 109, at 326 (for doubling or tripling of fee set on basis of full market value of time and effort reasonably expended on case, depending on approximate level of risk); Leubsdorf, supra note 102; Comment, supra note 25, at 708-09; Developments in the LawClass Actions, 89 HARV. L. REv. 1318, 1615 (1976) [hereinafter cited as Developments]. 
on the case. Similarly, punitive and deterrent rationales do not support the award of a contingency bonus. They may support assessinents beyond actual fees paid, but not in any correlation with whatever contingency bonus might be appropriate. ${ }^{115}$ In sum, with equity and incentive rationales that focus on the individual case, shifting of a contingency bonus does not appear justified.

Reasons for fee shifting that include broader purposes aiming beyond the particular case, however, afford a stronger basis for shifting a contingency bonus. If we want to encourage private attorney general suits, risky plaintiff' test litigation, or claims for nonmonetary relief, forbidding the shifting of coinpensation for risk could deter the bringing of such cases. ${ }^{116} \mathrm{~A}$ policymaker wishing to foster a public interest bar and a private bar imvolved generally in "public imterest" cases 117 could reasonably desire both to hold out to plaintiffs the prospect of full relief on their claims and to offer their attorneys the chance of a reasonable overall level of return from such litigation. ${ }^{118}$ It seems defensible, then, to extract some risk compensation from losing defendants in such cases rather than denying it entirely or leaving lawyers to seek it from their winning clients. ${ }^{119}$

2. Determination of the Amount to Be Shifted. Many fee shifting provisions speak in terms of the award of a "reasonable" attorney's fee. ${ }^{120}$ As a starting point, the widespread notion that what is "reasonable" should be determined by soine calculation of the fees that the prevailing party appropriately incurred has imtuitive appeal. ${ }^{121}$ When compensation provides the basis for an award this approach seems

115. Paradoxically, the more fitting a punitive award, the less appropriate a contingency bonus. Punitive assessments make sense, for example, if a defense was so weak it should never have been pressed - but in such a case the other side's risk of loss in contesting it is minimal, and the need for a risk premium absent. See Leubsdorf, supra note 102, at 474, 488-90; Developments, supra note 114, at 1615 . Litigants do not usually need extra encouragement to pursue sure winners.

116. See Comment, supra note 25 , at 709 (in cases for nonmonetary rehef, if loss from nonpayment in unsuccessful suits is not made up for in winning ones, either chent or lawyer will have to assume risk, which "is likely to deter vindication of protected rights").

117. See Aronson, supra note 57, at 287; Hermann \& Hoffmann, supra note 51, at 203-04; Nussbaum, supra note 51, at 311; Comment, Court-Awarded "Reasonable" Fees: Forcing a Segregated Public Interest Bar?, 7 FORDHAM URB. L.J. 399, 421 (1979).

118. See Leubsdorf, supra note 102, at $480,508$.

119. See McLaughlin, The Recovery of Attorney's Fees: A New Method of Financing Legal Services, 40 FordHAM L. Rev. 761, 784 (1972); Developments, supra note 114, at 1615.

120. See, e.g., 42 U.S.C. $\$ 2000 \mathrm{e}-5(\mathrm{k})$ (1976) (employment discrimination litigation).

121. A recurring issue in cases lacking broad impact and having small amounts at stake or secured as relief is whether it can ever be "reasonable" to award an attorney fee as large as, or even greater than, the damages. It may initially seem indefensibly uneconomical to allow fee payments of unore than a case's "worth." Nevertheless, strong arguments exist for permitting such awards, provided the court takes care not to reinburse time gratuitously run up. See, e.g., 
plainly correct, ${ }^{122}$ and the basic justice of the idea suggests that we should not depart from it without good ground to do so. One such reason might be concern for the transaction costs of determining fee awards, which could support adoption of specific guidelines based on the amount of damages recovered. ${ }^{123}$ Or to avoid any excessive disincentives of full indemnity, some fraction of the amount reasonably expended on legal services might be used as the starting point for fee award calculations. ${ }^{124}$

Moreover, some of the grounds other than compensation commonly regarded as bases for fee shifting do not require that amounts awarded bear any close relation to a prevailing party's actual expenditure. Punitive and deterrent rationales allow setting of the amount to be awarded at whatever level seems just and necessary. For purposes of those ends the award could as well be ten times or one tenth of the fee, or a sum bearing no necessary relation to the size of the fee, as it could be the actual amount itself, depending on how much condemnation we want to express and how much deterrence we seek to impose. ${ }^{125}$ Still, of course, we will often want to compensate the prevailing party for expenses he should not have had to pay, ${ }^{126}$ which supports including those expenses as one component of the amount awarded. But punitive and deterrent awards can go further: Federal Rule of Appellate

Furtado v. Bishop, 635 F.2d 915, 918-19 (1st Cir. 1980) (rejecting trial court's limit of one-half of damages for fee awards; emphasizing importance of adequate financing to get rights enforced).

Special problems arise in deciding how to set a fee award when a party, such as a Legal Services or pro bono client, receives the assistance of counsel at a below-market rate or for no charge. The emerging consensus in federal decisions allows fee awards in favor of a prevailing aided client calculated at market, not actual, cost. See, e.g., Copeland v. Marshall, 641 F.2d 880 (D.C. Cir. 1980) (en banc); Oldham v. Ehrich, 617 F.2d 163, 168-69 (8th Cir. 1980); Palmigiano v. Garrahy, 616 F.2d 598 (Ist Cir.), cert. denied, 449 U.S. 839 (1980). When the reasons for a fee shifting policy include encouraging the type of claim brought, this position seems justified. Even with compensation as the basis for fee shifting, use of a market rate would still be defensible to achieve the appropriate econo1mic level of deterrence. See infro note 122.

122. Moreover, calculating fee awards on a market cost basis provides the economically efficient level of deterrence against negligent infliction of loss, regarding a plaintiff's normal legal fees as part of his loss. See R. PosNER, supra note $16, \S 6.12$, at 143 ("the right amount of deterrence is produced by compelling negligent injurers to make good the victim's losses").

123. See AlASKa R. CIv. P. 82. Practical experience with such guidelines in Alaska, however, indicates that they cause contention and dissatisfaction. See generally Comment, supra note 70; House Hcarings, supra note 24, at 53 (testimony of Prof. C. Dallas Sands). And, of course, the amount recovered cannot provide a starting point for calculations in suits for nonmonetary relief or when defendants win verdicts of no liability.

124. See Wills \& Gold, supra note 90 , at 34,60 .

125. As far as punitive and deterrent functions are concerned, sanctions could just as well be fines payable to the court as awards to the adversary. Holding out the possibility of collecting the award or at least a portion of it, lowever, seems necessary as a practical matter to provide incentive for initiatives to enforce the sanctions.

126. See, e.g., Ruderer v. Fines, 614 F.2d 1128, 1132 (7th Cir. 1980). 
Procedure 38, for example, permits awards of damages and single or double costs in cases of frivolous appeals, ${ }^{127}$ and federal antitrust laws provide for treble damages. ${ }^{128}$

In a sense, when the question of such further assessments arises we leave the realm of fee shifting. Still, punishment and incentive effects often enough serve as possible grounds for fee shifting ${ }^{129}$ that it seems worth considering them in this context. The isolation of the separate bases and their implications provides a helpful reminder that in cases of behavior especially deserving of punishment or deterrence, the existence of a fee shifting scheme need not preclude the imposition of additional sanctions.

\section{Conclusions}

Beyond the by now obvious points that there are several possible rationales for attorney fee shifting, of varying degrees of persuasiveness, and that they have nunierous and wide-ranging implications, a few final observations emerge froin this study. First, a fee shifting system need not rest on just a single rationale; different reasons can coexist and support different aspects of the scheme. The rule for much civil rights litigation, for example, is that a prevailing plaintiff " should ordimarily recover an attorney's fee unless special circumstances would render such an award unjust." "130 A prevailing defendant, by contrast, may recover only "upon a finding that the plaintiff's action was frivolous, unreasonable, or without foundation, even though not brought in subjective bad faith."131 Underlying the standard for plamtiffs is the private attorney general idea that the plaintiffs vindicate " polic[ies] that Congress considered of the highest priority." "132 The same considerations are not present with prevailing defendants; 133 instead, the legislative concern seems to have been "to protect defendants from burdensome litigation having no legal or factual basis."134

Second, for the most part the varying rationales-even when involved simultaneously in an individual case-do not produce conflict-

127. See FED. R. APP. P. 38 ("If a court of appeals shall determine that an appeal is frivolous, it may award just damages and single or double costs to the appellee").

128. See, e.g., 15 U.S.C. \$ 15 (1976).

129. See, e.g., Comment, supra note 25 , at $652-53$ (focus on abuse of legal apparatus as basis for broadened fee shifting).

130. Christiansburg Garment Co. v. EEOC, 434 U.S. 412, 416-17 (1978) (quoting Newman v. Piggie Park Enters., 390 U.S. 400, 402 (1968)).

131. 434 U.S. at 421.

132. Id. at 416 (quoting Newman v. Piggie Park Enters., 390 U.S. at 402).

133. See 434 U.S. at 418.

134. Id. at 420 . 
ing indications for and against fee shifting that complicate decisions on its appropriateness. Rather, different grounds support fee shifting to different extents, but do not cut against it once they cease to support it while yet another basis remains. The concern for deterring groundless hitigation underlying limited fee shifting in favor of prevailing civil rights defendants, for example, would also support similar limited shifting for plamtiffs who prevail over determined but baseless resistance. The encouragement of claims vindicating important policies provides the basis for even unore extensive shifting in favor of prevailing plaimtiffs. ${ }^{135}$

Third, at least on the range of considerations surveyed in this article, the case for English-style general indemnity has appeared surprisingly weak and the argument for primarily one-way pro-prevailingplaintiff fee shifting surprisingly strong. The justifications for the latter are not confined to the encouragement of particular types of litigation a legislature may wish to favor, such as civil rights claims. Rather, the idea draws considerable support froin the generally accepted and widely applicable aim of making whole a party who has suffered legal injury. That aim, of course, can apply to a defendant subjected to litigation baselessly brought or continued as well as to a plaintiff entitled to compensatory damages. Reverse fee shifting in favor of such defendants seeins just and could also be important to prevent too many weak "nuisance" suits under a one-way rule. ${ }^{136}$ Legislatures and courts might, of course, balk at such a system, both because of the likely opposition of adversely affected interest groups such as liability insurers and also out of a sense of basic fairness - that fee shifting should generally be soinething available to both sides or neither. We have come to accept primarily one-way shifting in soune important areas, however, and my arguinent questions whether the apparent evenhandedness of general indemnity stands up to analysis as a justification for it.

Finally, my own preferences aside, $I$ hope that the exploration in this article can be helpful in clarifying the area for others. Beyond

135. The principal exception to this happy absence of conflict might arise from undesirable incentive effects of fee shifting felt to be justified on equity grounds. A general indemnity rule's feared effect of discouraging reasonable though not clear-cut claims of middle-class plaintiffs presents such a problem. But with the equity rationales that this article has viewed as the stronger ones, particularly that of making wronged parties whole for legal injury, such conflicts seem less likely to arise.

136. A feature that it might be desirable to add to any system along such one-way lines is provision for defendants to make offers of judgment at least canceling, and perhaps reversing, the shif of post-offer fees if the plaintiff rejects the offer and does not do better at trial. See generally, e.g. Zander, Payment into Court, 125 NEw L.J. 638 (1975) (effectiveness of "payment in" device under English indemnity rule). But see P. ATTYAH, Accidents, CoMpensation aND the LAW 308-11 (3d ed. 1980) (harshness and distortions from workings of "payment in" rule). 
mere clarification, the discussion here of the merits of several rationales for fee shifting may also illustrate that pohicy questions in this area need not be approached solely from angles of ideology or interest. The kinds of considerations examined in this article are of course not the only ones that do or ought to determine our policies on who should bear the costs of litigation; tradition, the imterests of affected groups, political ideologies, and the perceived incentive effects of fee shifting rules will imevitably play a major role. We can and should, nonetheless, draw guidance from principled legal arguinent not only in the application of our fee shifting policies but also in their formulation. 